\title{
Who are the officials in the central administration of the Czech Republic and what activities do they perform?
}

\begin{abstract}
The article examines the section of officials in the central administration who belong to the ministerial staff of the Czech Republic. It examines those persons engaged in the creation of analyses, strategies, and management activities. The study is based on original research conducted by the ministries of the Czech Republic in $2013(N=1351)$. The article seeks to discover what the make-up of this group is in terms of gender, age, and education levels at the chosen ministries, as well as to report on the types of experiences the group has had. The analysis shows that ministerial officials are in fact a gender-balanced group of employees, predominately university-educated. The overall median age of employees in all ministries is 42 years. On the other hand, there are certain inter-ministerial differences, as explained in detail in this paper. Based on results of the empirical research, conclusions have been drawn that may also serve as an inspiration for similar investigations in other countries of Central and Eastern Europe that address similar issues as found in the Czech Republic.
\end{abstract}

KEYWORDS: officials in central administration, ministerial staff of the Czech Republic, ratio of employed men and women, level of education of the ministerial staff

RECEIVED 8 October 2015; ACCEPTED 1 February 2017.

\section{INTRODUCTION}

This study examines the officials in the central administration who belong to the ministerial staffs in the Czech Republic. It analyses those who deal with analytical, planning, conceptual, strategic, and control activities. The problem so far has not been studied in the Czech Republic. An exception is the studies by Veselý (2014) and Nekola and Kohoutek (2016). In other countries, we find a relatively large number of works dealing with similar issues. We used these works to create a conceptual framework, which is detailed in a subsequent part of the study. Based on our own empirical survey of officials in central administration who work in the ministries of the Czech Republic, we aim to: (a) explore age, gender, and educational composition, (b) identify what types of experiences they have had, (c) make comparisons among the ministries, and draw conclusions from the findings. The study is divided into several parts. In the first section, we create a conceptual framework for exploration. We search for a suitable theoretical background required for our investigation, we define research questions, and provide the characteristics of data collection. The second part of the study focuses on the analysis of results of the empirical research and discusses the findings in terms of age, gender, education, and experience as well as other characteristics. The conclusion carries out a synthesis of results of the empirical research and makes recommendations for further investigation.

\section{BASIS OF EXAMINATION AND RESEARCH OUESTIONS}

Performance within a public administration depends on various factors. One key factor that affects the efficient functioning of the central administration is the officials in the central administration. The problems associated with officials in public administration

\footnotetext{
1 František Ochrana, Michal Plaček: Centre for Social and Economic Studies, Faculty of Social Sciences, Charles University. Milan Křápek: Private College of Economic Studies,
}

Znojmo. Emails: ochrana@fsv.cuni.cz,390046@mail.muni.cz, krapek@svse.cz 
is addressed in the literature from different perspectives. The first group comprises authors who study the role of policy workers in public administration. These include Dunn (2004), Dobuzinskis, Laycock, and Howlett (2007), Howlett (2009) Colebatch, Hoppe, and Noordegraaf (2010), Rasmussen (1999), Evans, Lum, and Shields (2011) Veselý, Wellstead, and Evans (2014). The aforementioned group of authors are engaged in activities and roles of policy workers in public administration. These works and, particularly the studies by Howlett (2009) Colebatch, Hoppe, and Noordegraaf (2010), Veselý (2014), became the inspiration for creation of our plan for empirical research. Regarding the Czech Republic, the first investigation of this issue was carried out by Veselý (2014) as part of his research project P404/12/0725 'Analysts of policy in the central government administration of the Czech Republic: practices, professional values and identity'. Other members of the research team of Professor Veselý also contributed to the general understanding of this issue, as well as Nekola, and Kohoutek (2016), Ochrana, Plaček, and Křápek (2015). The second discussion perspective was offered by authors who are dedicated to the problem of policy bureaucracy. These include Christensen, Fimreite and Lægreid (2007) who investigated the reform of employment and welfare administration, and Jon Peters (2003) who explains the current problems of public administration. An important inspiration for this examination was offered by the publication of Peters and Jenkins (2005), and in particular, the analysis of the world of policy bureaucrat. Publications, which inspired the creation of a framework for our research, dealt with the reality of the Czech Republic. These include the studies of Novotný, and Hejzlarová (2011), which deals with the status of reflection of public policies in the Czech Republic, articles examining policy work and policy analysis (Veselý, 2012; Hejzlarová, 2010), a book analysing the reform of public administration in the Czech Republic (Půček et al., 2009) and a study of public policy (Novotný, 2012; 2015; Veselý \& Nekola, 2007).

The third major discussion group consists of works by authors who deal with the problem of reforms in public administration. These include Pollit and Bouckaert (2011), who evaluated reforms in public administration in various countries. Drechsler and Kattel (2008), Nemec (2010), Dan (2015), Dan and Pollitt (2015) and Randma-Liiv, Nakrošis and Gyorgy (2011) public administration reform in the former Soviet bloc countries and assessed the impact of NPM on these reforms. The works mentioned above are particularly important for understanding and explaining the conceptual framework of the reform of public administration from the perspective of our analysis and to analyse activities performed by officials in central administration in terms of ongoing reforms of public administration. Our empirical research conducted on the ministerial staff of the Czech Republic covers the period when ongoing reform of public administration in the Czech Republic was built on the ideas of NPM. In the Czech Republic, the NPM ideas are reflected in the formation of the government strategy 'Efficient public administration and friendly public services. Strategy of the realization of Smart Administration for the period 2007-2015' (abbreviated as Strategy Smart Administration). This document was adopted by Government Resolution no. 757 in 2007.

It is somewhat surprising that the Czech Republic was focused on NPM at a time when the idea of NPM had been declared by some authorities as 'dead' (Dunleavy et al., 2006) or outdated (Drechsler \& Kattel, 2008). The focus on NPM was primarily for political reasons. The details are described in the study Ochrana et al. (2016). The Czech Republic was looking for foreign models that were clearly (in content and form) different from any semblance of the public administration under the communist regime. Therefore, the former government, led by the right-wing Civic Democratic Party, was looking for a model of liberal-oriented reforms of public administration. They found them in the reforms of the United Kingdom and in the idea of NPM. The idea of NPM became the main motive for creating the Strategy of Smart Administration and permeated the contents of this document, which aimed to create an effective public administration.

The document Strategy Smart Administration defines six key factors that should be established regarding public administration reform. These factors are shown in the form of Hexagon Public Administration. Hexagon Public Administration consists of the following factors: Legislation, Organization, Citizen, Technologies, Finance, and the Official Public Administration factor. These factors are viewed from the position of NPM: Legislation is a regulatory tool that creates a legal framework for the functioning of public administration. It was assumed that the 'good' regulatory rules would automatically lead to 'good regulation'. The organization of public administration is formed to achieve maximum performance so that citizens are the satisfied clients of public administration. Regarding organization, public administration is viewed as a production system whose efficiency can be measured based on trade inputs / outputs. Technology is considered to be a means of the efficient functioning of public administration. A key role is played by the official (bureaucrat) within public administration. Smart Administration strategy characterizes it as 'the Cornerstone of public administration' (Smart Administration strategy, p. 57), and adds: 'And it is not important whether it is a ministry official or an official of the state administration having delegated powers in a region or municipality. Officials should be treated equally everywhere; a high level of performance should be required as well as continuous learning. Emphasis should be placed, in particular, 
on quality management at all levels' (Smart Administration Strategy p. 57). This paragraph ends with a brief description of the public administration official. A further analysis Smart Administration strategy is not addressed. Nothing in this condition has changed including the recently adopted government strategy 'Strategic Framework for Development of Public Administration of the Czech Republic for 2014-2020' (2015). There is, therefore, a significant deficit regarding the knowledge of who the officials in central administration in the Czech Republic are, and who creates the ministerial staff. Veselý et al. (2013) point out in their own research that a distorted view exists among the Czech public regarding officials in central administration. These include the opinion that the Ministerial Officials are elderly, uneducated, inefficient, and the Ministry is primarily run by men. The public opinion is reinforced by the fact that the public does not communicate directly with the ministerial officials. The public gets information about the work of ministerial officials indirectly, based on the appearance of ministers, deputy ministers and spokespersons of the ministries. The work carried out by the ministerial officials remains 'hidden' in the eyes of the public. This reinforces public speculation about what the ministerial officials actually do. Given this gap in knowledge regarding the officials in central administration in the Czech Republic, we put the following research questions in our article:

1. What is the age and gender composition of ministerial officials? Is the public assumption that the ministries mainly employ men and that the officials are too old valid?

2. What is the educational structure of the ministries? Is the public assumption that the ministerial officials are uneducated valid?

3. How are individual ministries distinguished in terms of education, age, gender, and work experience?

To answer these questions, we offer our own data collection.

\section{DATA}

For the analysis of officials in central administration in the Czech Republic, ${ }^{2}$ our own empirical research was carried out on the ministries of the Czech Republic. The research was conducted in the months of April to June 2013. The research was preceded by interviews with a group of about twenty employees from several ministries. The interviews were conducted in the autumn of 2012. The research was conducted within the research project of the Grant Agency of the Czech Republic 404/12/0725 P 'Analysts of policy in the central government administration of the Czech Republic: practices, professional values and identity' in collaboration with the agency STEM / MARK.

The subject of investigation was the profile of ministerial workers who are directly engaged in the creation of strategies and analysis. Employees of ministries who are engaged in such activities as maintenance, operation of the secretariat, accounting, 'general administration', and the like were not included in this study. The basis for the selection of respondents was a list of potential respondents who worked in individual ministries. We interviewed people from all 14 ministries of the Czech Republic. Three ministries opted not to participate in the research (the Ministry of Interior, the Ministry of Regional Development, and the Ministry of Agriculture). The selection of respondents and the method of contacting them depended on the lists and contacts of the officials we received from various ministries. Respondents were selected randomly. A series of random selections were addressed and all (or almost all) of the entities were included in the database of individual ministries. Thus, random selection became an almost exhaustive sampling. The method of interviewing the respondents was as follows: eight ministries through personal interviews (F2F - face-toface), a form containing the prescribed questions to be filled by the respondents, either in the form of paper questionnaires (i.e., PAPI) or using by a laptop (i.e., PAPI). In the two ministries, the questioning was carried out by the sole use of filled-in form in the form of online questionnaire (i.e., CAWI) without the participation of the interviewer as an 'emergency' form of solution, when it was not possible to obtain answers in the form of F2F. In one case, a combination of both methods (F2F and CAWI) were utilized. A total of 1,351 respondents were interviewed. The youngest respondent was 22 years old, and the oldest respondent was 76 years old. Most of the questionnaires were filled through PAPI (992 questionnaires), 124 questionnaires were filled using CAPI, and

2 In the Czech Republic, the status of staff of the Czech Republic ministries is provided by Act No. 2/1969 Coll., on the establishment of ministries and other central government bodies of public administration, as amended (the so-called Competence Act). This Act lists the individual ministries and concisely assigns them specified activities. All these activities are either directly or indirectly performed by employees of the ministries. 
235 questionnaires through CAWI. As per the latest research conducted by Bouchal and Janský (2014), 19,141 officials work in ministries, approximately. Our sample of 1,351 respondents is, therefore, statistically significant. The 95\% significance level had a statistical error of $2.57 \%$, and a significance level of $99 \%$ had a statistical error of $3.38 \%$. To achieve statistical significance, a sample of 377 respondents was sufficient.

\section{RESULTS OF THE INVESTIGATION AND DISCUSSION}

In this part of the study, answers to research questions will be sought followed by a debate on the results of the empirical research. We will examine whether the prevailing public opinions (see Veselý, 2013) about the unbalanced age structure, dominance of men over women, and poor education levels of ministerial staff are true.

\section{Age structure and gender composition of the ministerial staff}

In this part of the study, we will answer the first research question. We will examine what is the age and gender composition of ministerial officials. Our empirical research has given the following answer to this question (Table 1).

Tab. 1: Age composition and gender characteristics of the ministerial staff

\begin{tabular}{ccccccccccccc}
\hline & Total & MLSA & MJ & MF & MT & MH & ME & MEYS & MFA & MC & MIT & MD \\
\hline Median staff age & 42 & 35 & 35 & 35 & 38 & 38 & 38 & 40 & 44 & 45 & 46 & 50 \\
\hline $\begin{array}{c}\text { Sex \% } \\
\begin{array}{c}\text { male/female/no } \\
\text { response }\end{array}\end{array}$ & $50 / 50 / 1$ & $34 / 66$ & $34 / 66$ & $48 / 52$ & $60 / 39 / 1$ & $29 / 71$ & $46 / 50 / 4$ & $38 / 61 / 1$ & $67 / 30 / 3$ & $37 / 63$ & $54 / 46$ & $84 / 16$ \\
\hline
\end{tabular}

Source: own research.

MD - Ministry of Defence, MLSA - Ministry of Labour and Social Affairs, MC - Ministry of Culture, MH - Ministry of Health, MF - Ministry of Finance, MT - Ministry of Transport, MJ - Ministry of Justice, ME - Ministry of the Environment, MIT - Ministry of Industry and Trade, MEYS Ministry of Education, Youth and Sports, MFA - Ministry of Foreign Affairs

The lay public belief that ministries are staffed mostly by male employees proved to be a myth. On the contrary, the research results have produced evidence that, in total, for all ministries, the ratio of men to women is perfectly balanced. Nevertheless, the fact is that the proportion of men and women differs among individual ministries. When we subject the research sample to the chisquare test (on the significance level of both 0.05 and 0.01 ), we discover that in terms of gender balance, there are differences among the ministries. The highest contribution to the chi-square test results were from the Ministry of Defence, where the analysed group consisted of an $84 \%$ share dominated by male employees. However, the test would still show differences even if the Department of Defence was, as an extreme case, removed from the sample of tested ministries.

The different result for the Ministry of Defence can be explained by the fact that the staff is essentially made up of former soldiers, who upon retiring into the reserves become civilian employees of the ministry. This assumption reinforces the fact that the Ministry of Defence has $61 \%$ of surveyed employees in the age interval of 45-59 years, which corresponds to the age group when professional soldiers, following the fulfilment of their enlistment, retire into the reserves and remain at the Ministry of Defence to work as civilian employees. The fact that Defence is still traditionally seen as a male profession in the public eye also substantially contributes towards the predominance of male employees in the Defence sector.

When we the age structure of the examined group of employees from all ministries, we find that half of all the surveyed employees are less than 42 years old. The age structure in individual age groups is shown in Figure 1. 
Fig.1: Surveyed employees age structure

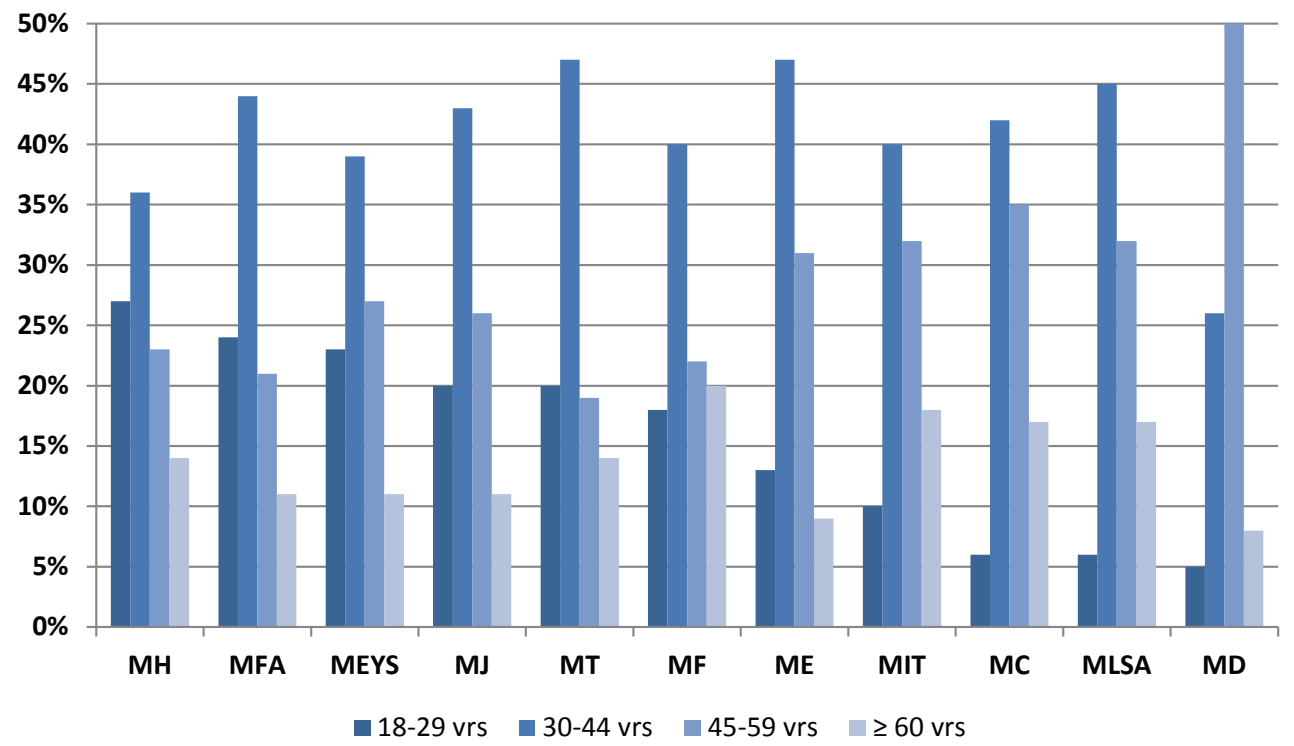

Source: own research; for abbreviations see Table 1.

The analysis of age structure of the examined group of employees from all ministries thus refutes the widespread public assumption of 'overage' ministries. Individual ministries, however, differ in their age structure, as shown in Figure 1. Adoption of the chi-square test also confirmed that the factor of specific ministries ('type' of ministry) has an impact on the age of employees. We may even say that there is a moderate dependence (expressed by the Spearman's correlation coefficient of 0.369) between individual ministries and the age of their employees.

Of the surveyed ministries, the Ministry of Labour and Social Affairs, the Ministry of Finance, and the Ministry of Justice, which have the lowest median age, attract the most attention (apart from the Ministry of Defence with the highest median age of 50 years). This is likely due to several factors. First, all these ministries have a strong (in the interval 40-45\%) representation of employees in the age group 30-44 years old that ranks them among the 'young ministries'. Apart from that, it may be assumed that the 'fact of youth' of the aforementioned ministries also influences the reality that the employees of these ministries upon completion of relevant schooling become students of law, finance and public policy study fields; these students, who upon graduation apply for a job at the concerned ministries, had worked for these ministries previously (i.e., during the period of their full-time university study) on a part-time basis. Following their graduation from the university, they proceed to a full-time employment at the given ministries.

The fact that graduates, who had already worked for the relevant ministry during their studies, have become one of major sources of replenishment of the ministerial officials induces changes in the age structure of the given ministries. This effect can be illustrated by a comparison of the Ministry of Finance (a 'young' ministry) with the Ministry of Defence (an 'old' ministry).

In the Ministry of Finance, exactly one-fifth of the surveyed employees are over 60 years of age. This is the maximum when compared to all the examined ministries. Yet, the Ministry of Finance is one of the 'young' ministries. In comparison, the Ministry of Defence has only $8 \%$ of its workforce in the age group over 60 years, which is the lowest of all the ministries. Nevertheless, the Ministry of Defence ranks as an 'old' ministry.

However, the Ministry of Defence (ceteris paribus) currently does not have many options to change the status quo. Personnel principles and a career system in the Ministry of Defence are, in fact, set up so that they do not allow the application of a similar procedure as in the case of other ('young') ministries. Full-time students studying at a military school cannot be simultaneously employed as ministerial officers, because regulations do not allow it. This is one of the relevant factors that influence the median age.

Another factor that may influence the average age of the given ministry is a higher proportion of secondary educated employees in the examined group of workers. This can be illustrated by the case of the Ministry of Justice (median age 35 years), where a fifth of the examined group of workers had secondary education while being comprised of a generally young staff who come to their 
posts immediately after their graduation, respectively, within a relatively short time after completion of schooling. In the case of the Ministry of Defence (median age 50 years), there are no such posts available where only secondary education would be sufficient. This is also the factor of the age imbalance.

\section{Analysis of the ministerial staff in terms of education, experience and self-reflection on own work performance}

In this part of the study, we will seek answers to the second and third research questions. Gradually, we will examine what the structure of education among officials within the ministries, and how individual ministries differ from each other in terms of education, age, gender and work experience.

\section{Analysis of the education structure of ministries}

The attained level of education for the examined sample of ministerial staff was monitored under the following categories: a) apprenticeship/high school without A-levels (diploma), b) secondary education with A-levels (diploma), c) higher professional education, d) university undergraduate (bachelor degree), e) university graduate (master degree) and f) university doctoral education. Results of the empirical research are shown in Figure 2.

Fig. 2: Educational structure per ministries

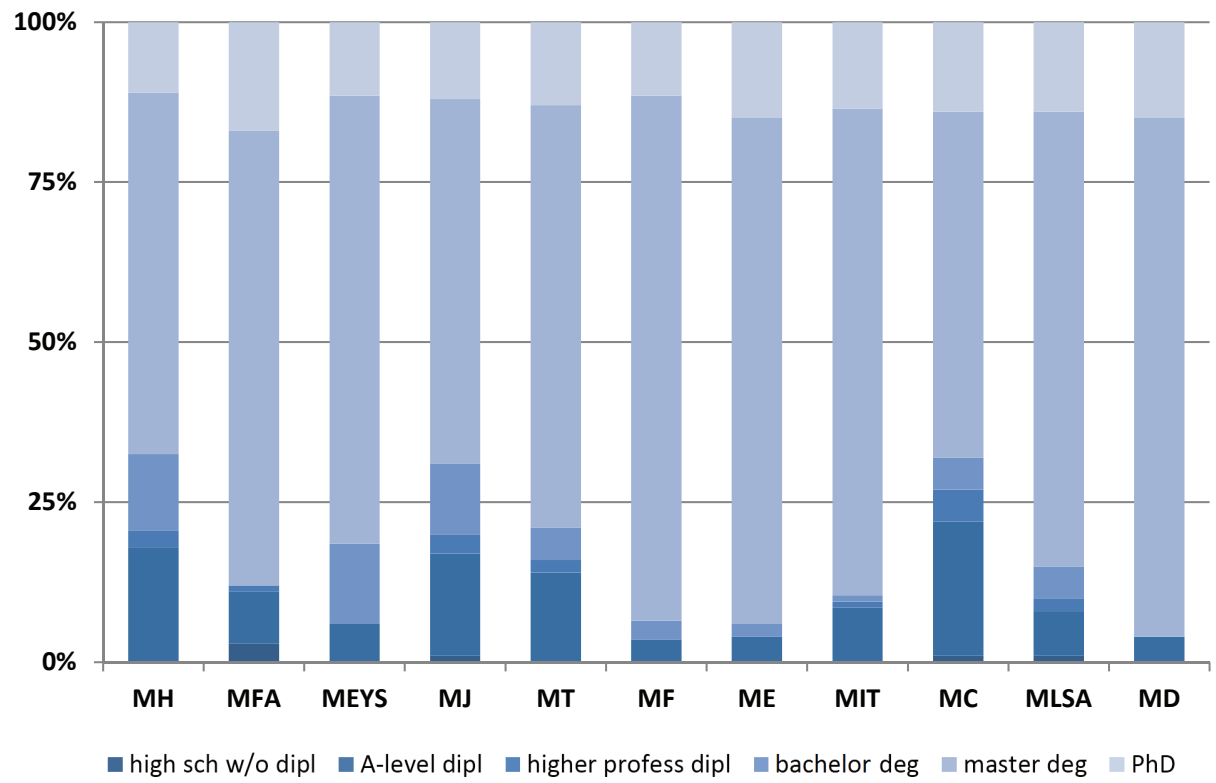

Source: own research; for abbreviations see Table 1.

The chart shows the alignment of ministries having the largest share of employees with university-degree education with the ministry having the lowest proportion of university-educated employees. From the perspective of education, all the ministries have on an average $89 \%$ university-educated employees, which is a relatively high proportion. However, at the same time, our research shows that, among individual ministries, there are obvious differences. In this context, we asked whether there is a correlation between the type of ministry and the educational level of its employees. Since we did not anticipate a linear dependence, we calculated using Spearman's correlation coefficient which amounted to 0.30549 . This value may be interpreted as a weak dependency. 
The highest proportion of university-educated employees (including completed doctoral studies) was achieved by the Ministry of Defence, which has within the examined group $96 \%$ of its employees having a university degree. A similar high proportion of university graduates in the examined group (95\%) was achieved by the Ministry of Environment. On the other hand, there is a group of ministries (such as the Ministry of Justice, Ministry of Transport, Ministry of Health and Ministry of Culture) which possesses a proportion of university-educated employees at 75 to $80 \%$ overall among employees. How can this difference be explained?

It turns out that there are ministries where dealing with certain tasks require (i.e., it is sufficient) only a secondary-degree education with A-levels (diploma). Such cases are typical for the Ministry of Health and the Ministry of Culture, where several tasks related to policy analysis are performed by employees with only a secondary-level education. Legislation rules permit such procedures and outcomes. That is, individual ministries on their own submit their proposals to the Government Office related to the staff number and the required qualifications. Therefore, for this reason, there also may emerge differences in the education structures within individual ministries.

\section{A comparison of ministries in terms of education, age and gender}

Within the following analysis, we shall, by certain means, attempt to compare ministries in terms of the age factor, attained education and gender balance. The results of our examination are shown in Table 2.

Tab. 2: Grouping of ministries based on education and age

\begin{tabular}{|c|c|c|c|}
\hline \multicolumn{4}{|c|}{ Education level (coefficient of education, respectively) } \\
\hline $\begin{array}{l}\text { Age level } \\
\text { (coefficient of age, respectively) }\end{array}$ & 1 & 2 & 3 \\
\hline 5 & & & $\operatorname{MD}(83.93 \%)$ \\
\hline 4 & $\mathrm{MC}(36.69 \%)$ & $\operatorname{MIT}(53.41 \%)$ & $\mathrm{MH}(69.70 \%)$ \\
\hline 3 & & & MF (48.00\%) \\
\hline \multirow[t]{3}{*}{2} & MT (6o.19\%) & MEYS (38.27\%) & ME (47.83\%) \\
\hline & $\mathrm{MJ}(34.62 \%)$ & & \\
\hline & MFA (29.92 \%) & & \\
\hline 1 & & MLSA (33.90\%) & \\
\hline
\end{tabular}

Source: own research.

The starting point for building clusters of ministries is the relationship between education, the age of respondents and the proportion of male workers to the total number of employees (expressed in \%) of a given ministry. For the grouping of ministries, the evaluation criteria were adopted that rank ministries according to the attained education level, and according to age. The education level is shown by the coefficient of education that takes values from 1 to 3 depending on the 'education' of the given ministry. Thus, higher the education of a given ministry, higher the coefficient of education will be. The ministries with the lowest coefficient of education were included in education level 1, while those with the highest coefficient of education were included in education level 3.

The age levels cluster ministries into five age levels based on the age of their employees. The higher the age of the ministerial staff, the higher the age level (see the Ministry of Defence) and vice versa (see the Ministry of Labour and Social Affairs).

This method produces groups (clusters) of ministries as shown in Figure 1. From the clusters of ministries, the solitary Ministry of Labour and Social Affairs and the isolated Ministry of Defence with the highest age of the examined group stand out. If we examine the dependency of education and average age (correlation coefficient of 0.4581 ), we find that the coefficient of education of the ministries and the average age has a weak direct linear relationship.

The analysis of data shows that the ministries which have a higher proportion of male employees also have a higher average age, while this relationship points towards a strong linear dependency (correlation coefficient of 0.7369). A comprehensive explanation of the problem requires further research. It is difficult to find a satisfactory answer to how can this relationship be explained. It could 
be partly because men retire at a higher age as compared to women. At the same time, it is probably also significant that men tend to 'put off' their retirement, despite the fact they are already entitled to draw an old-age pension. Another explanation is that men often remain in posts of the examined group of ministerial staff even when they are already retired.

Such a group of seniors, who already receive an old-age pension (or postpone their retirement though they are entitled to it), may be found at the Ministry of Finance. In this ministry, the 'senior group of employees' represents nearly one-fifth of the examined sample of employees. The members of 'senior group' of policy workers also behave similarly in the other ministries. A specific case is exhibited by the Ministry of Defence. Least number of examined group of staff, that is, only $8 \%$ of employees are found in the advanced age (over 60 years). On the other hand, the Ministry of Defence has, as compared to other ministries, more than double the number of the examined group of staff in the age group of $45-59$ years (in total $61 \%$ share). This is due to the fact that in this group of staff, the so-called military veterans and pensioners, who after their retirement into reserves receive a service pension, but often remain civil officials of the Ministry of Defence. Thus, at the same time they receive a service pension and the salary for the post they hold. This economic stimulus likely affects the high number of the examined group of staff in this age group of employees of the Ministry of Defence.

As evident from the research (see the detected lowest proportion of examined group of ministerial staff over 60 years of age), the administration of the Ministry of Defence responds to this situation such that after completion of 60 years of life, i.e. when former professional soldiers are entitled to their retirement pension, their employment contract terminates. This pressure from the management of the Ministry of Defence leads to the lowest proportion of examined group of employees over 60 years of age from all ministries.

How can it be explained that within all ministries, more than a tenth of the examined group of ministerial staff (on average 13\%) are more than 60 years old, and approximately one third of the workers are aged 45 to 59 years? Why does the proportion of men and women in these age categories differ? This is probably given by the different value-based world of senior men and senior women. Women pass relatively easier into retirement since they have a wider range of interests (care of grandchildren, study at the University of the Third Age, creative home chores, etc.). In comparison, the number of hobbies for men is lower or even altogether absent. This hypothesis was not a subject of the original research. It was established only based on the data collected during the research and several subsequent probing interviews at several ministries. We envisage its verification within one of subsequent empirical pieces of research.

\section{Access of ministerial staff to further education in terms of gender}

While resolving this issue, we have posed the question: What access to further education do ministerial staff (men and women) have? An analysis of this issue has revealed that the ministries with a higher proportion of male staff have a higher coefficient of education. The given dependence is moderately strong (correlation coefficient of 0.6887). It is an interesting finding that presents evidence of a certain general problem, that is, inequality in real access (not potential, but formally, legal equal access) to the highest (especially doctoral) level of education after the thirtieth year of life. In case the graduates do not enrol directly into doctoral studies after completing their university studies and embark onto postgraduate courses (almost without exception of distant-form), only after a certain period of time (e.g., around or after their thirtieth year), the conditions for studying for women and men effectively changes. When deciding upon starting doctoral studies, women of this age consider their existing or anticipated parental responsibilities, or they possibly already are caring for family and children, and consider their further studies to be incompatible with their parental and family responsibilities. The result is a negative decision to continue with further studies. The results of the analysis (see Figure 1) point to this fact when the determined relatively lower coefficient of education (factor 1) applies to those ministries where there is a higher representation of women. The identified issue thus takes the form of a gender-based problem of (real) unbalanced access of education to women through a distant-form of doctoral studies starting at about thirty years of age. This finding was very surprising to the ministerial executives since they have had no knowledge of this unequal access of men and women to further education.

Based on this finding, we have, at the same time, asked whether the unbalanced ratio of men and women in doctoral studies also affects the relatively higher proportion of secondary-educated employees in the entire sample of some ministries, such as the cluster where the Ministry of Health, Ministry of Justice and Ministry of Transport belong, or outside the cluster such as the Ministry of Culture, where the proportion of secondary-educated workers marginally exceeds a fifth of the sample. All these cases are 
'young' ministries when their average age may be reduced by the relatively higher proportion of young secondary-educated workers, employed in the posts of analysts. This hypothesis has been subjected to a further investigation using the chi-square test and the test confirmed this hypothesis. The shares of 'relatively young' secondary-educated workers aged 30, 35 and 40 years do not differ among ministries.

\section{Role of experience in the performance of ministerial staff}

The next research question posed examined what role is played in addressing the assignment experience of ministerial workers, expressed by the number of years of service in the ministry. We have encountered a problem of this specification while preparing the research, when in the autumn of 2012, interviews were conducted with a group of several dozen ministerial employees. After the issue of the nature of managed tasks and the role of experience was established, a part of respondents expressed the view that for solving analytical tasks, years of experience are required. This problem was succinctly expressed by one of the respondents from the Ministry of Defence by the statement: 'The reason we are so old is because to pursue activities, experience that can only be obtained through a relatively long praxis in the ministry is necessary. Moreover, the tasks are so complex that they require previous experience.'

This assumption seems to be rational. Indeed, it can be assumed that for solving complex problems previous experience is required, expressed by the number of years of service in the ministry. Is it so?

To look for the answer to this problem, we have adopted the following procedure. We started from the assumption that there are ministries where age (measured by the median) is higher because the nature of handled tasks is so complex that processing them is dependent on previous work experience. We expressed the dimension of work experience by the number of years worked at the ministry and the size and complexity of the handled tasks by the nature of the tasks which 'do not a have an exclusive, clear cut and relatively simple solution'. On the other hand, simple and routine tasks were identified by multiple choice questions, when tasks 'have an exclusive, clear cut and relatively simple solution'. Answers about the nature and frequency (measured as a percentage of required work time) of handled tasks were obtained from the respondents' answers. The results of the correlation analysis, which point towards the relationship between the number of years worked at the ministry and the nature of handled tasks (tasks with multiple solutions / tasks with an exclusive solution), are shown in Table 3.

Tab. 3: Results of the correlation analysis (number of years worked and complexity of handled tasks)

\begin{tabular}{|c|c|c|c|c|}
\hline \multicolumn{5}{|l|}{ Variable } \\
\hline & \multicolumn{4}{|c|}{ Marked correlations are significant at the significance level of $p<0.05$} \\
\hline & \multicolumn{4}{|c|}{$N=1,281($ Complete cases omitted for ChD) } \\
\hline & Employment status & Multiple solutions & Exclusive solution & Age \\
\hline Employment status & 1.000000 & -0.027977 & 0.069583 & 0.734528 \\
\hline Multiple solutions & -0.027977 & 1.000000 & 0.132707 & -0.072995 \\
\hline Exclusive solution & 0.069583 & 0.132707 & 1.000000 & 0.010109 \\
\hline Age & 0.734528 & -0.072995 & 0.010109 & 1.000000 \\
\hline
\end{tabular}

Source: own research

Results of the examination do not confirm the given presumption that the time spent working in the ministry is a factor that corresponds with the complexity of handled tasks. There is only a very weak correlation between age and handling of complex tasks. This means that handling complex tasks does not depend on the length of previous experience and it is neither significantly dependent on the physical age as a factor, which was assumed, that brings a higher accumulation of experience that significantly enhances handling of complex tasks. As Table 3 shows, all values are too weak to confirm the validity of this hypothesis.

With respect to the issue of complexity of the handled tasks and the expected higher degree of empirical experience gained through the employment time at ministries, an issue appeared of whether ministries that have, on examined posts, a higher number 
of secondary-educated employees perform more activities that have an exclusive, clear cut and relatively simple solution, or in fact perform fewer activities that do not have an exclusive, clear cut and simple solution? In other words, is it possible to prove that the factor of attained education (secondary/university) of ministerial workers correlates to the perception of the nature (complexity simplicity) of the handled tasks? Are there differences in the number of secondary-educated and university-educated workers in individual ministries given by the nature of the complexity/simplicity of the handled tasks?

The research results (carried out at 5\% level of significance, see Table 2) did not prove the expected differences among the ministries. Individual ministries are therefore not significantly different from the perspective of perceived difficulty of the handled tasks related to attained education. It does not therefore hold true that ministries with a higher proportion of secondary-educated workers would perform a larger volume of simple activities than ministries with a smaller number of secondary-educated employees. Also, it was not proven that the ministries that have a higher number of university-educated workers would increasingly handle tasks that do not have an exclusive, clear cut and relatively simple solution, rather than ministries that have a relatively lower number of university-educated employees.

\section{CONCLUSION}

Results from the research yielded interesting findings. The analysis of literature and documents, which was done during the creation of the conceptual framework, leads to the conclusion that although the government of the Czech Republic aims to reform public administration and seeks inspiration from the reforms implemented in other (mainly Western European) countries, the results received from government documents are largely misguided. Government documents have been only partially implemented. This also applies to the Smart Administration Strategy, the implementation of which has been reduced to the computerization of public administration. The causes of the 'freezing' of reforms in public administration require a separate detailed analysis and comprehensive disclosure of the causes. In our study, we did not aim to find the answers to this question. However, we believe that one of the reasons may be that all the governments have chosen 'imitate and catch up with Western European countries' as a strategy without sufficiently learning from any imperfections and mistakes of otherwise successfully implemented reforms. The Czech government, during the creation of reform documents, was largely inspired by the 'technique' carried out in the successful reforms in other countries. They put the emphasis on 'technology' side of the reforms. It was even demonstrated in the case of Strategy of Smart Administration (public administration reform = e-governance). The quality and sufficiency of officials within public administration is a key factor for the implementation of reforms. The government documents do not (verbally) acknowledge this point (see the designation of officials of public administration as 'the cornerstone of public administration'), whereas, in fact, there is large gap in knowledge regarding who these officials are and what activities they perform. If the performance capacity of these officials is not known, such as the activities which they perform during working hours, then this ignorance can be a serious factor in the inefficiency of government reforms and may lead to the demotivation of staff at the ministries.

An empirical analysis regarding officials in central administration led to the following findings. First, it became apparent that the public presumptions that ministerial officials are elderly, uneducated bureaucrats, do not reflect reality. Empirical research revealed that the individual ministries differ in mean age and age structure, but overall, in terms of gender, they were perfectly balanced. The general public's view, that the ministerial officials are elderly, has been proved illusory. Half of the respondents were younger than 42 years old. Differences were discovered among the various ministries, however. These are given by variety of factors already mentioned. Differences among ministries could also be caused due to some specific circumstances that can be shown, for example, in the case of the Ministry of Labour and Social Affairs, the Ministry of Finance (both 'young' ministries,) and the Ministry of Defence (the 'old' Ministry). From our work experience as university teachers, we know from the first hand that some students work in the ministries while still studying (namely, at the Ministry of Labour and Social Affairs and the Ministry of Finance) and then continue working there after their graduation. This probably has an influence on the young age of these ministries, even in the case of the Ministry of Finance, where a fifth of the respondents who worked there were over 60 years old. In the case of the Ministry of Defence, such a practice is not possible. Students at universities cannot be employed during their studies at the Ministry of Defence. Internal rules do not allow this at the Ministry of Defence. Additionally, at the Ministry of Defence, there are many so-called 'military activities' which require relatively longer experience within the units. All this taken together leads to the fact that the examined group of workers from the Ministry of Defence has the highest average age of all the ministries (48 years). These conclusions regarding the 
age structure, however, are hypotheses that would need to be examined in further researches. Moreover, the analysis of education shows that ministerial officials obtained high levels of education. Overall, $89 \%$ of employees surveyed in the sample have a university education. It distorts the general public's idea of uneducated officials. But the fact is that individual ministries differ, however, in the proportion of college students. In terms of this indicator, the Ministry of Defence has the most highly educated employees, where $96 \%$ of employees have a master's degree and/or doctoral education. On the other hand, there are ministries, where the representation of college graduates is $75 \%$ - $80 \%$ (e.g., The Ministry of Justice, the Ministry of Health). This is probably due to the systematization of jobs. The systematization of jobs refers to a personnel activity that creates a prescribed number of posts at the ministry with predetermined education levels. In the Czech Republic, this is performed so that the number of staff at the ministries (including the proposed qualifications) are proposed by the ministries themselves, which are then approved by the government (or the Ministry of the Interior). The Ministry of Health and the Ministry of Justice have, therefore, planned a defined number of places at certain positions for officials with a prescribed secondary education. However, this is merely a hypothesis. Verification of this would be useful via other researches regarding the effectiveness of the civil service law. The factor of the Civil Service Act was not contained in the empirical research nor included in our study as the research (2013) preceded the formation of a timetable for the effectiveness of the civil service law, which had been approved by Parliament in mid-2014 and came into force on 1 January 2015.

Also, in terms of work experience, the empirical research brought up some findings. The findings revealed that $44 \%$ of the surveyed officials had been in the same position for up to three years, while $13 \%$ of respondents had worked in the same position for more than 11 years. The 'lay' hypothesis claiming that employees of ministries 'sit' in the category of long-term office holders does not reflect the reality. When we check the number of years the given employees worked at a ministry, we would find, on average (quite expectedly) that they have been working at the ministry longer than they have been in their current positions. Over $70 \%$ of the employees have been working at a ministry for more than three years, with approximately half of the employees doing so for more than 5 years. The findings also show that majority of surveyed employees had an experience of working in the public administration. In total, $70 \%$ of respondents had already worked in the public service for more than 5 years; a fifth of the respondents had worked for over 20 years. Also, in this case, there were differences among individual departments. These were based on various factors which may be the subject of further research. Finally, it may be generally established that the results of empirical analysis regarding officials in central administration reveal some new knowledge which may contribute towards a deeper understanding, as well as serve as an inspiration for similar investigations in other countries of Central and Eastern Europe, and could possibly be used for the purpose of comparative analysis.

\section{ACKNOWLEDGEMENTS}

This paper is processed as an output of the research project P-17 'Science of a society, politics and media within challenges of the time' by the Faculty of Social Sciences, Charles University in Prague, and research project TD 03000018 (OMEGA) 'Using the results of social science research in analytical activities focusing on strategic decision-making and public administration’.

\section{REFERENCES}

Bouchal, P. \& Janský, P. (2014). State officials: How many exist, where and how much are they paid to work. . Praha: IDEA CERGE EI.

Christensen, T., Fimreite, A.L., \& Lægreid, P. (2006). Reform of the employment and welfare administration - the challenges of cocoordinating diverse public organizations. International Review of Administrative Sciences, 73 (3), 389-408.

Colebatch, H. K., Hoppe, R., \& Noordegraaf, M. (eds.) (2010). Working for Policy. Amsterdam: University Press.

Dan S. (2015). The New Public Management is Not That Bad After All: Evidence from Estonia, Hungary and Romania. Transylvanian Review of Administrative Sciences, 44E/205, 57-73.
Dan, S. \& Pollitt, Ch. (2015). NPM can work: an optimistic review of impact of new public management reforms in Central and Eastern Europe. Public Management Review, 15(9), 1305-1332.

Dobuzinskis, L., Laycock, D., \& Howlett, M. (2007). Policy analysis in Canada: The state of the art. Toronto: University of Toronto Press.

Dunleavy, P., Margets, H., Bastow, S. \& Tinkler, J. (2006). New public management is dead - long live digital governence. Journal of Public Administration Research and Theory, 16(3), 467-494.

Drechsler, W. \& Kattel, R. (2008). Towards the Neo-Weberian State? Perhaps, but certainly adieu NPM! NISPAcee Journal of Public Administration and Policy, 1(2), 95-99. 
Dunn, W. N. (2004). Public Policy Analysis: An Introduction (3rd edition). Upper Saddle River, NJ: Prentice Hall.

Evans, B., Lum, J., \& Shields, J. (2011). The State of Policy Capacity in Canada: Assessments from Senior Public Servants, 16-18. Paper delivered at the 83rd annual meeting of the Canadian Political Science Association. Waterloo: Wilfrid Laurier University.

Hejzlarová, E.M. (2010). Policy analysis in the Czech Republic: positivist or postpositivist? Central European Journal of Public Policy, 4(2), 88-107.

Howlett, M. (2009). Policy analytical capacity and evidence-based policy-making: lessons from Canada. Canadian Public Administration, 52 (2), 153-173.

Howlett, M., (2011). Public Managers as the Missing Variable in Policy Studies: An Empirical Investigation Using Canadian Data. Review of Policy Research. 28(3), 247-263.

Nekola, M. \& Kohoutek,), J. (2016). Policy work at the sub-national level: Analytical styles of Canadian and Czech directors and managers. Canadian Public Administration/Administration Publique du Canada. 59(2), 289-309.

Nemec, J. (2010). New Public Management and Its Implementation in CEE: What Do We Know and Where Do We Go? Nispa Journal of Public Adminisration and Policy, 3(1), 31-52.

Novotný, V. (2012). Vývoj českého studia veřejných politik v evropském kontextu [Development of Czech public policy studies in the European context], Praha: Karolinum.

Novotný, V. (2015). Czech study of public policy in the perspective of three dominant approaches. Central European Journal of Public Policy, 9(1), 8-48.

Novotný, V. \& Hejzlarová, E. M. (2011). Lesk a bída české analýzy veřejných politik. Vývoj a aktuální stav z pohledu vnějších vlivů [Splendors and Miseries of Czech Policy Analysis: Its State and Development in the Perspective of External Influences]. Politologická Revue 17 (1), 3-32.

Ochrana, F., Plaček, M. \& Křápek, M. (2015). Ministerial Staff o the Czech Republic. Proceedings of the 11 th International Scientific Conference. Public Economics and Administraion 2015. Ostrava - Technical University of Ostrava. Faculty of Economics, 146-151.

Ochrana, F., Plaček, M. \& Půček, M. (2016). Shortfall of Strategic Governance and Strategic Management in the Czech Republic. Central European Journal Public Policy. 10(2) DOI: 10.1515/cejpp-2016-0024.
Peters, B. G. \& Jon, P. (Eds.) (2003). Handbook of Public Administration. London - Thousand Oaks - New Delhi.

Pollitt, Ch. \& Bouckaert, G. (2011). Public Management Reform. A Comparative Analysis. New Public Management, Governance, and the Neo-weberian state. Third edition. Oxford: University Press.

Půček, M., Ochrana, F. et al. (2009). Smart Administration. Cohesion Policy. Prague: Ministry for Regional Development.

Rasmussen, K. (1999). Policy capacity in Saskatchewan: Strengthening the equilibrium, Canadian Public Administration, 42 (3), 331-348.

Randma-Liiv, T., Nakrošis, V., \& Gyorgy, H. (2011). Public sector organization in Central and Eastern Europe: From agencification to deagencification, Transylvanian Review of Administrative Sciences, Special Issue (35), 160-165.

Veselý, A. (2012). Policy advisory system in the Czech Republic: from state monopoly to hollowing out? Paper presented at the XXIInd World Congress of Political Science in Madrid.

Veselý, A. (2013). The survey of employees of central administration (ministries) directly subordinate organizations. Final Report. Praha: Centrum pro sociální a ekonomické strategie.

Veselý, A. (2014). The Profile and Work of Officials in Central and Regional Administration Compared: The Case of the Czech Republic. NISPAcee Journal, 7(1), 107-128.

Veselý, A. \& Nekola, M. (Eds.) (2007) Analýza a tvorba veřejné politiky: prístupy, metody a praxe [Methods of policy analysis and design]. Praha: SLON.

Veselý, A., Wellstead, A., \& Evans, B. (2014). Comparing sub-national policy workers in Canada and the Czech Republic: Who are they, what they do, and why it matters? Policy and Society, 33(2), 103-115.

Efficient public administration and friendly public services. Strategy Smart Administration in the Period 2007-2015. Praha: Ministerstvo vnitra.

The strategic framework for the development of public administration of the Czech Republic for 2014-2020 "(2015). In the text of the resolution no. 21 from January 14, 2015. Praha: Ministerstvo vnitra. 